\title{
REPRESENTING KIN(G)SHIP IN MEDIEVAL IRISH LITERATURE
}

\author{
Nahir I. Otaño Gracia
}

Medieval Irish literature often depicts a reciprocal relationship among community members - men, women, and even the land - who all partake in choosing the king. The works tend to explore issues surrounding kingship and heroism, often questioning the actions of the kings and heroes when they lead the community towards danger and strife. In many cases, both the Irish law tracts and tales are preoccupied with kingship and succession. It is worth investigating then what the relationship is between the law and the literature in regards to kingship. Bart Jaski suggests that there is a discrepancy between early Irish laws and narrative literature. On the representation of kings in the literature, he concludes that "the overall impression is that the sources express an ideal rather than a precondition for rulership. It added to a king's royal stature if he showed those qualities the early Irish writers and poets cultivated, but we can be sure that not all Irish kings were as good, wise, brave, strong and handsome as their legendary role-models."1 Jaski describes narrative texts as tales that idealized kings.

Through an investigation of the power structures between king and subject in the literature, I maintain that the actions of the king had repercussions for the rest of the community represented in the tales, and that these members could praise as well as question and criticize the actions that harmed the community. ${ }^{2}$ Expanding on Jaski's framework, this paper argues that an analysis of kingship in literature points toward the idea that the kings and the heroes who could attain sovereignty might often have been idealized but were also rather carefully scrutinized. The representation of kingship in both the law texts and the literature have a very important similarity: the king is chosen by election by a "culture of aristocrats within a stratified heroic society." 3 The Irish notions of honor and heroism are connected to the sovereignty of the leader. A Celtic leader and his immediate family can lose sovereignty because kingship is not necessarily passed down from one generation to the next. Sovereignty is earned to a certain degree, and a younger leader can take it away from another man if the former is proven worthy through battle prowess and/or good judgment. ${ }^{4}$ If the king misuses his fir

I would like to thank the amazing community of medievalists at the University of Pennsylvania, especially my post-doctoral mentor Rita Copeland for her continuous support.

${ }^{1}$ Bart Jaski, Early Irish Kingship and Succession (Dublin: Four Courts Press, 2000), 88.

${ }^{2}$ Because the texts omit those of lower status such as slaves and commoners, the community described within them is not representative of actual medieval Irish communities, but of an idealized community.

${ }^{3}$ D. Blair Gibson, From Chiefdom to State in Early Ireland (Cambridge: Cambridge University Press, 2012), 13, Kindle edition.

${ }^{4}$ Indeed, as Amy C. Mulligan points out, Macha Mongrúad wins the kingship over the kingly men of Ireland by being an effective leader over them. First, she beats Cimbáeth and Díthorba in battle, gaining the kingship from them. Then, she is a "producer of kingly discourse of power" by

ENARRATIO 22 (2018)

(C) 2019 Otaño Gracia. This article is published under a Creative Commons Attribution-NonCommercial-NoDerivatives 4.0 International License (https://creativecommons.org/licenses/by-nc-nd/4.0/) 
flathemon ("ruler's/prince's truth/justice") ${ }^{5}$ makes the wrong decisions, or is unfair in his ruling, the land will not produce and his subjects will suffer, creating an opening for a new leader to step forward and obtain the sovereignty. In Irish literature, the leader and the heroes can take center stage equally because good kings are praised, heroes represent the future prospects of the community, and the son of a king can only become king if he can win sovereignty, giving the community a way to criticize and glorify those in power and those who might hold power.

Following Jaski's distinction between early Irish laws and narrative literature, this essay divides its analysis into two sections. The first section introduces kingship, laying out the relationship of the king and his subjects. The section describes some of the terms that define secular kingship, as expressed in several of the law tracts. ${ }^{6}$ Scholars such as Kelly Fergus, D. Blair Gibson, Jaski, and Riitta Latvio among others have analyzed the law tracts to find commonalities within this expansive, and often contradictory, body of texts. They have exposed the importance of friendship between a king and his retinue, including the fili or the poet, and they highlight the contractual nature of the relationship. ${ }^{7}$ This contractual nature of early Irish discourse, its give-and-take quality, should be kept in mind in the study of the differing levels of authority. ${ }^{8}$ Indeed, the title of

denying the kingship to the sons of Díthorba. Finally, she overcomes the sons in battle. See Amy C. Mulligan, "Playing for Power: Macha Mongrúad's Sovereign Performance," in Constructing Gender in Medieval Ireland, ed. Sarah Sheehan and Ann Dooley (New York: Palgrave Macmillan, 2013), 83, Kindle edition. Mulligan writes that Macha behaves "as a good king, using the right formulas, respecting social codes, and refraining from impetuous, ill-advised judgements regarding fitting punishment of offenders, an act that when performed out of the ruler's self-interest rather than society's well-being can cause a king's downfall” (89).

${ }^{5}$ Jaski, Early Irish Kingship, 72.

${ }^{6}$ Early Irish law tracts are a product of Old Irish law-texts composed between the seventh and ninth centuries. They have been extensively rewritten throughout the Middle Ages, and survive in manuscripts dating from the fourteenth to the sixteenth century. Fergus Kelly, A Guide to Early Irish Law (1988; repr., Dublin: Dublin Institute for Advanced Studies, 2015), 1. Irish law tracts include Crith Gablach, Uraicecht Becc, Míadslechta, Uraicecht na Ríar, and Bretha Nemed, among others. Daniel A. Binchy dates Crith Gablach c. 700 and Uraicecht Becc to the seventh or eighth century (Crith Gablach [Dublin: Dublin Institute for Advanced Studies, 1941], and "The Date and Provenance of Uraicect Becc," Ériu: The Journal of the School of Irish Learning 18 [1958], 44-54).. Eóin MacNeill dates Miadslechta to the eighth century ("Ancient Irish Law. The Law of Status or Franchise," Proceedings of the Royal Irish Academy 36 [1923]: 265-316). Liam Breatnach dates Bretha Nemed and Uraicecht na Riar to the eighth century ("Canon Law and Secular Law in Early Ireland: The Significance of Bretha Nemed," Peritia 3 (1984): 439-59, and Liam Breatnach, ed., Uraicecht na Ríar: The Poetic Grades in Early Irish Law [Dublin: Dublin Institute for Advanced Studies, 1987]). One of the most important collections on the subject continues to be Studies in Early Irish Law by Rudolf Thurneysen, et al. (Dublin: Hodges, Figgis and Co., 1936). For an extensive introduction on the subject, see Kelly, A Guide to Early Irish Law; and Jaski, Early Irish Kingship, 37-56.

${ }^{7}$ For more information on Irish kingship, see Daniel A. Binchy, Celtic and Anglo-Saxon Kingship (Oxford: Clarendon Press, 1970); Thomas M. Charles-Edwards, Early Irish and Welsh Kinship (Oxford: Oxford University Press 1993), and "A Contract between King and People in Early Medieval Ireland? Crith Gablach on Kingship," Peritia 8 (1994): 107-19; Jaski, Early Irish

Kingship; Francis J. Byrne, Irish Kings and High-Kings (Dublin: Four Courts Press, 2001); Riitta Latvio, "Status and Exchange in Early Irish Laws," Studia Celtica Fennica 2 (2005): 67-96; Mark Joseph Zumbuhl, "The Practice of Irish Kingship in the Central Middle Ages." (PhD diss., University of Glasgow, 2005); and Gibson, From Chiefdom to State, among others.

${ }^{8}$ Latvio describes the exchange between the king and his subjects as a contract:"whether it was the fancy of the medieval jurists or a social reality, the early Irish discourse was penetrated by 
this paper uses the term kin(g)ship to articulate the complicated relationship of king and subject in medieval Irish texts.

The second section expands on the relationship of the king and his subjects, introducing the important role of the community (male and female) in Irish literature. The section introduces the sovereignty motif and analyses three tales from the Ulster cycle-Scéla Conchobair maic Nessa ("The Tidings of Conchobar Son of Ness") also known as Compert Conchobuir, ${ }^{9}$ Mesca Ulad ("The Intoxication of the Ulstermen"), ${ }^{10}$ and Loinges mac nUislenn ("The Exile of the Sons of Uisliu") ${ }^{11}$ - defining the ways that these texts both praise and scorn those who place the community in danger. Moreover, these texts include women as part of the community that elect and question those in power. The women introduced in the tales-Ness, Emer, and Deirdre - have a say in validating Conchobar as king and have an important political and legal role within the community represented in the stories. The women become part of the community that chooses the king.

\section{HISTORY, LAW, AND KIN(G)SHIP}

There were many types of kings in Ireland. The Irish words ri, ruiri, and rig ruirech refer to different levels of kingship. In Ireland, there were many, perhaps hundreds, of groups called túath ('people,' 'laity,' 'tribe,' 'territory,' or 'petty kingdom'), and each of the groups had a king. ${ }^{12}$ The $r i$ was the "the king of an individual túath." 13 The word $r i$ is a cognate with Indo-European terms rex, reich, and $r a j$, showing its basis in a long history of kingship. ${ }^{14}$ The position of the $r i$ is

contractual thinking and language." She concludes that "the status relationships in early Ireland were largely based on two reciprocal models between superior and inferior parties. ... The reciprocal agreements offered relative security even for the inferior party in an honor-based society, as the status of the superior was bound to his fairness and the fulfilling of his obligations towards the inferior." Latvio, "Status and Exchange," 90, 91.

${ }^{9}$ The tale is found in the Book of Leinster (Dublin, Trinity College, MS 1339) and is dated to the twelfth century and written in early Middle Irish. See Whitley Stokes, ed. and trans., "Tidings of Conchobar Mac Nessa," Ériu: The Journal of the School of Irish Learning 4 (1910): 18-38.

${ }^{10}$ There are two versions of the tale; this essay discusses the version found in the Book of Leinster, and was written c. 1100. See J. Carmichael Watson, ed., Mesca Ulad (Dublin: Dublin Institute for Advanced Studies, 1983).

${ }^{11}$ There are several versions of the tale, including those found in the Book of Leinster and the Yellow Book of Lecan (fourteenth century; Dublin, Trinity College, MS 1318). Vernan Hull dates the oldest language to the eighth or ninth century. See Hull, ed., Loinges mac nUislenn, The Exile of the Sons of Uisliu (New York: Modern Language Association, 1949).

12 Jaski, Early Irish Kingship, 38. Gibson defines tuath as "the most elemental Irish chiefdom." From Chiefdom to State, 14. Kelly describes tuath as "the basic territorial unit," A Guide to Irish Law, 3 .

${ }^{13}$ Zumbuhl, "The Practice of Irish Kingship," 22. Though Gibson uses the terms "chief," "chieftain," and "chiefdom" to describe the Irish social structure as supposed to "king," "tribe," "clan," or "lordship" because they are more correct from an anthropological perspective (From Chiefdom to State, 14-16), this paper continues to use the terminology favored by historians such as Jaski and Kelly.

${ }^{14}$ Jaski, Early Irish Kingship, 38; and Kim McCone, “'King' and 'Queen' in Celtic and IndoEuropean," Ériu: The Journal of the School of Irish Learning 49 (1998): 1-12. Gibson agrees that the term shows an affinity with "other early European terms for a leader of ruler" but does not necessarily show that they are cognates. He argues that "these terms may jointly derive from a 
closely aligned with wealth of goods, animals, and land and with a contractual relationship between the chief and his subjects. It seems that the ri played a major role in making war and peace with other tuatha, and his ability to make the right decisions was connected to the prosperity of the land. The ri needed to make the right choices for his people and his land to prosper, which was the hallmark of a good king. The Irish system of kingship is also complicated by the fact that kings at one level could become subjects of stronger kings, pointing to a hierarchy of kingship. ${ }^{15}$ The rí and his túatha could have an overking, the ruiri (great king) or ri túath (king of tribes). The ruiri was overlord of the kings of several túatha and could also be under the kingship of a stronger over-king known as ri ruirech or ri cóicid, namely the king of a province or supreme king. ${ }^{16}$

The role, definition, and function of both the túath and ri are described as a contractual obligation between both parties. ${ }^{17}$ The king must represent and lead the túath in both political and military matters against other túatha, and he must maintain the safety and order of his túath. Jaski explains that "the rule of a king can be beneficial to the people, but his powers are clearly related to the duties he is to carry out. King and people form two equal parties and their relationship is based on mutual cooperation." "18 The Crith Gablach, for example, describes the king's duties to defend his people and to be a just judge; in exchange, the king can summon them to a hosting (slógad), an edict or ordinance (cána or rechtgae), and an alliance treaty with other túatha. ${ }^{19}$ Lawfully the relationship between king and people is one of reciprocity; the túatha chose their kings. The succession between one king and the next is not decided simply by primogeniture or might; rather there is a complicated system of succession.

Eóin Mac Neill synthesizes the laws on succession into three tenets. First, the eligible candidate (rígdomna) must be connected to the previous king, through the derbfine of the king. Second, the derbfine is defined as the family of the previous king by four generations - king, sons, grandsons, and great grandsons. Finally, the king is chosen from the derbfine by election from the aristocratic men

common Proto-Indo-European source, but that is no guarantee that the descendant institutions to which these derivatives refer are isomorphic." From Chiefdom to State, 15.

${ }^{15}$ Jaski, Early Irish Kingship, 99-102. Jaski points out that there are multiple levels of kingship, but that the law tracts are not consistent with the terms used to describe these differing levels of chieftains.

${ }^{16}$ Even if the titles existed, Byrne finds that the over-kings who seem to be competing for Ireland from the ninth century onward were essentially rig túaithe. Byrne, Irish Kings and High-Kings, 4047. Kelly gives the terminology used in the Crith Gablach. He asserts that "the lowest grade of king, the rí túaithe, ruled over a single tribe ... Above him was the ri túath 'king of tribes', who, as well as ruling his own tribe, received tribute from the kings of three or four other tribes. Above the ri túath was the rí cóicid 'king of a province'. The ard-rí or 'high king' of Ireland does not emerge until the ninth century, and is never mentioned in the text of the Laws." Fergus Kelly, ed., Audacht Morainn (Dublin: The Dublin Institute for Advanced Studies, 1976), xvi. Kelly's explanation also serves as an example of the abundance of terminology on kingship in the early Irish law texts, which is one of the reasons that the Irish law tracts have produced so much scholarly debate, an in-depth discussion of which is beyond the scope of this study. Nonetheless, focusing on the relationship between the kings with their people, specifically the relationship between the ri with his tuatha, demonstrates the give and take quality of early Irish kingship

${ }^{17}$ Jaski, Early Irish Kingship, 37-56; and Latvio, "Status and Exchange," 90.

${ }^{18}$ Jaski, Early Irish Kingship, 48.

${ }^{19}$ Latvio, "Status and Exchange," 90. See also Charles-Edwards, “A Contract," 107-19; and Kelly, A Guide to Irish Law, 21-22. 
of the community. ${ }^{20}$ In other words, the men eligible to become king were those connected to the previous king within four generations and the new king was chosen from among those eligible to the kingship. Although Irish succession was, in practice, more complicated than these three tenets, they are helpful in understanding early Irish kingship. As the information provided above shows, the rigdomna is a man who is eligible to succeed to kingship. The tánaise rig (heirdesignate or heir-apparent), however, is the one that normally does become the next king. ${ }^{21}$ Furthermore, the tánaise ríg could die, be killed, get married, and so on, allowing for the other eligible candidates to succeed to kingship. It is clear from the detailed information available on the law tracts that succession was an important aspect of the relationship between the people and the king. How much these rules were followed and how they might have changed meaning through time continue to be important questions.

Apart from the tenets above, to be eligible to become king, a person should possess the following traits, among others: to have "good legal standing" (innraic), to be innocent of theft, to be free from any physical blemishes, and to have property. ${ }^{22}$ Perhaps the most important characteristic is associated with the concept of fir flathemon, defined above. The truth or justice of those in power indicates their ability to rule and to maintain a reciprocal relationship with their people and the land. Kelly Fergus explains that fir flathemon "protects [the king's] tribe from plague, lighting, and enemy attack and ensures abundance of fruit, corn, milk, and fish, fertility of women, and maintenance of peace and prosperity."23 One of the ways the king maintains his position of power through the power of truth is by keeping up with his obligations to the community.

The wisdom-text Audacht Morainn ("The Testament of Morann") combines many of the elements mentioned above. Audacht Morainn can be categorized as a speculum principis (mirror of princes), ${ }^{24}$ and it begins by explaining that it was sent to Feradach Find Fechtnach by the mythical judge Morann son of Móendeals. ${ }^{25}$ The text aims to instruct the young king Feredach on how to be kingly. Audacht Morainn connects justice with the reciprocal relationship

\footnotetext{
${ }^{20}$ Eóin MacNeill, Celtic Ireland (1921; repr., Dublin: Academic Press, 1988), 114. Irish rulers were elected only by the highest elite men; women, for example, had no legal role in electing the kings.

${ }^{21}$ Dáibhí Ó Cróinín, Early Medieval Ireland: 400-1200 (London: Longman, 1995), 67-68; and Immo Warntjes, "Regnal Succession in Early Medieval Ireland," Journal of Medieval History 30, (2004): 389-90. Ó Cróinín points out that "the tánaise . . was certainly expected to succeed to the kingship and, so far as I can see from the evidence, he invariably did. In the law tract Crith Gablach the term tánaise ríg is explained in this way: 'The tánaise ríg, why is he so called? Because the whole tribe looks forward to him for the kingship without dispute.' This can hardly be reconciled with the concept of rigdomna, which is nowhere taken to imply that the person so called is expected to succeed." Early Medieval Ireland, 67-68. Ó Cróinín uses Eóin MacNeill's translation of Crith Gablach in "Ancient Irish Law," 300.

${ }^{22}$ Ó Cróinín, Early Medieval Ireland, 70.

${ }^{23}$ Kelly, Audacht, xvii. Kelly uses the word corn to mean cereals such as barley, oats, rye, and wheat. The word is not describing maize or its descendants from the Americas.

${ }^{24}$ Kelly, Audacht, xiii. There are several extant versions of Audacht Morainn. Recension A has been edited and translated by Rudolf Thurneysen, "Morands Fürstenspiegel," Zeitschrift für Celtische Philologie 11 (1917): 56-106. Recension B has been edited and translated by Kelly Fergus, Audacht. This paper uses Kelly's version of the text.

${ }^{25}$ Fergus, Audacht, 2-3.
} 
between the king and his tribe; after all that is one of the central themes of the text - that the tribe and the king need his fir flathemon to thrive. ${ }^{26}$

After the text contextualizes the reasons for the testament to exist, the narrator, Morann, begins his advice in the following manner:

$\S 4 \quad$ Comath mo chosc íarmothá sund.

$\S 5$ (4) Sluind dó re cech bréithir,

Beir dó for cech bréithir inso sírchosc.

$\S 6$ (7) Comath firinni, cotn-ofathar.

$\S 7$ Turcbath firinni, tan-uircéba.

$\S 8$ (8) Ocbath trócairi cotn-océba.

$\S 9$ Coicleth a thúatha, cot-céillfetar.

$\S 10 \quad$ Fairtheth a thúatha, fa-rresat.

$\S 11$ Tálgeth a thúatha, tan-áilgebat."

$\S 4 \quad$ Let him keep my advice which follows here.

$\S 5$ Tell him before every [other] word,

Bring him with every word this lasting advice.

$\S 6 \quad$ Let him preserve justice (firinne), it will preserve him.

$\S 7 \quad$ Let him raise justice (firinne), it will raise him.

$\S 8 \quad$ Let him exalt mercy (trócaire), it will exalt him.

$\S 9$ Let him care for his tribes, they will care for him.

$\S 10 \quad$ Let him help his tribes, they will help him.

$\S 11$ Let him soothe his tribes, they will soothe him. ${ }^{27}$

The Dictionary of the Irish Language (DIL) defines firinne as "justice, righteousness" in old Irish and "truth" in Middle Irish. It also defines trócaire as "mercy" and in the laws as "leniency, equity." 28 The advice begins by asking the young king to carry out these ideologies. Then, the text moves to accentuate the give-and-take relationship of the king with his tribes. ${ }^{29}$ The advice of Morann to Feradach begins by associating justice, mercy (but also equity) with the relationship of the king and his people. Audacht Morainn continues with one of the oldest sections of the text, which brings up the king's fir flathemon (translated as justice $)^{30}$ and describes what the justice of the king brings to the community:

$\S 12$ (10b) Apair fris, is tre fír flathemon mortlithi (mórslóg no) márlóchet di doínib dingbatar.

13 (10a) Is tre fír flathemon conid( ?) márthúatha mármoíni midethar.

\footnotetext{
${ }^{26}$ Binchy, Celtic and Anglo-Saxon Kingship, 10; Kelly, Audacht, xvii; and Christophe Archan, "Ordeal by Fire in Medieval Ireland," Peritia 24-25 (2013-14): 198

${ }^{27}$ Kelly, Audacht, 4, 5 (emphasis added).

${ }^{28}$ Dictionary of the Irish Language: Based Mainly on Old and Middle Irish Materials, Compact Edition (1983; repr., Dublin: Royal Irish Academy, 2007), 308, 608.

${ }^{29}$ Kelly, Audacht, xvii.

${ }^{30}$ Kelly, Audacht, xvii, xliv.
} 
$\S 14$ (13a) Is tre f. fl. fo- síd sámi sube soad sádili -sláini.

$\S 15$ (11) Is tre f. fl. ath- (mór)cathu fri crícha comnámat -cuirethar.

$\S 20$ (23) Is tre f. fl. to- aidble (uisce) éisc i sruthaib -snáither.

$\S 2 \mathrm{I}(26 \mathrm{a}) \quad$ Is tre f. fl. clanda caini cain-tussimter. (deraib dethe)

$\S 22$ (27) Apair fris, os hé oec, oec a flaith.”

$\S 12$ Tell him, it is through the justice of the ruler that plagues [and] great lightnings are kept from the people.

$\S 13$ It is through the justice of the ruler that he judges great tribes [and] great riches.

$\S 14$ It is through the justice of the ruler that he secures peace, tranquility, joy, ease, [and] comfort.

$\S 15$ It is through the justice of the ruler that he dispatches (great) battalions to the borders of hostile neighbours.

$\S 20$ It is through the justice of the ruler that abundance of fish swim in streams.

$\S 21$ It is through the justice of the ruler that fair children are well begotten. (with tears(?) of ... ?)

$\$ 22$ Tell him, since he is young, his rule is young. ${ }^{31}$

Fir flathemon brings prosperity, bounty of food and wealth, peace and joy, and even children. The section goes on to bring up what the king would gain from fir flathemon, mainly that his kingdom would be protected and thriving. Audacht Morainn introduces the reader to the ideal qualities of a king, a king that is in communion with his subjects and that helps his community-the men, women, animals, and land - to thrive.

Audacht Morainn uses the concept of fir flathemon to instruct one on how to be an ideal king. Nevertheless, the Ulster tales discussed below do not always idealize Conchobar's kingship; the texts both praise and question his kingship. The tales seem at odds with the legal texts that introduce the ideals of kingship. The role of the poet or the fili (plural filid), as described in the law, is particularly helpful for understanding the connections between narrative and legal representations of kingship. The law tracts Uraicecht na Riar (The Primer of Stipulations or the Poetic Grades) and Bretha Nemed Toísech (Judgments Concerning Privileged Persons) discuss the role of the filid. The filid were the poets and learned men of the culture. Similar to kings, the position of the filid has several levels and sub-levels in which the filid could belong. The Uraicecht na Riar mentions seven types of poets and lists several of the conditions the filid had to follow. ${ }^{32}$ Tomás Ó Cathasaigh writes that "the poet must be learned, and he must be innocent of unjust defamation and of theft, plunder and illegality; he must

\footnotetext{
${ }^{31}$ Kelly, Audacht, 6, 7.

${ }^{32}$ See Liam Breatnach, ed. and trans., "The First Third of Bretha Nemed Tóisech," Ériu: The Journal of the School of Irish Learning 40 (1989): 16-17, and Uraicecht na Riar, 20-57, 102-15. See also Latvio, "Status and Exchange," 78.
} 
have only one wife, with whom he may have intercourse on the nights when it is lawful to do so." 33 The poets had an important role in Old Irish society because they had access to information that could benefit those around them. ${ }^{34}$ They were in charge of learning and remembering the past and had access to the history and literature of Ireland. ${ }^{35}$ Latvio indicates that in Bretha Nemed the power of the poet comes from his "prophetical techniques." 36 The fili performed language to praise and satirize those in power, ${ }^{37}$ creating a system of checks and balances for the kings and the men of rank. ${ }^{38}$ Ó Cathasaigh synthesizes the role of the fili and the patrons of the fili in the following manner:

The role of the fili as purveyor of praise and blame was inherited from pre-Christian times. We can be sure too that the traditional poets and learned men conserved the narrative and genealogical lore of the ruling classes. ... The patrons of the filid were either the kings and nobles, or the church. There is a good deal of evidence that the clerics, the filid and the jurists exercised their respective roles within a single literary and scholarly establishment. ${ }^{39}$

\footnotetext{
${ }^{33}$ Tomás Ó Cathasaigh, "The Literature of Medieval Ireland to c. 800: St. Patrick to the Vikings," in The Cambridge History of Irish Literature, ed. Margaret Kelleher and Philip O'Leary (Cambridge: Cambridge University Press, 2008), 20.

${ }^{34}$ Myles Dillon and Nora K. Chadwick describe the fili in the following manner. "Most important of all [was] the poet (fili), who seems to have inherited much of the prestige of the druid of pagan times. His duty was first of all to praise his patron, but also to preserve his genealogy, to be learned in history and literature, and to be a master of the craft of poetry. There are tracts prescribing the metres he must learn, the number of tales he must know, and the other learned works he must study, during a course of twelve years. He demanded rich rewards for his service, and he was likely to satirize a thrifty prince or nobleman." The Celtic Realms (London: Weidenfeld and Nicolson, 1967),
} 90-91

${ }^{35}$ See Breatnach, Uraicecht na Ríar, 102-03; Dillon and Chadwick, The Celtic Realms, 230. The tale-types that the fili should know according to the law tracts coincide with some of the names of the surviving tales. They include the "comperta (conceptions)," "tochmarca (wooings)," "echtrai (expeditions [to the Otherworld])," "immrama (sea voyages)," "togla (destructions)" and "tána bó (cattle raids)" to name a few. Ó Cathasaigh, "The Literature of Medieval Ireland," 24.

${ }^{36}$ Latvio, "Status and Exchange," 78. Robin Chapman Stacey skillfully describes the importance of performing the law, describing the jurists as poets who convey "through their verdicts a truth validated not merely by their knowledge of the law, but also by their access as verbal artists to otherworldly insight." Dark Speech: The Performance of Law in Early Ireland (Philadelphia: University of Pennsylvania Press, 2007), 83. On poets, Bretha Nemed states: "O wealthy mighty Morand, tell me how the power of every lawfully established nemed is estimated, for it is on the basis of privileges that every upright lawful skilled person is chosen (?). 'Great knowledge which illuminates', extempore chanting, the singing of anamain of four varieties are what confer dignity on a sage" ("A Moraind a maine a mochta, abuir frium co miter nert cach naosad nemedh, ar is a nemtesaib do-ecclamar cach direch dana dligid. Imus for-osnam, dicedul do cenduib, cedul nanomuin cethirriach cato cach suad"). Breatnach, Uraicecht na Ríar, 37, 36.

${ }^{37}$ See Pádraig A. Breatnach, "The Chief's Poet," Proceedings of the Royal Irish Academy 83C (1983): 37-79; Katharine Simms, "The Poet as Chieftain's Widow: Bardic Elegies," in Sages, Saints, and Storytellers: Celtic Studies in Honor of Professor James Carney, ed. Donnchadh O Corráin, Liam Breatnach and Kim McCone (Maynooth: An Sagart, 1989), 400-11.

${ }^{38}$ Amy C. Mulligan, "The Satire of the Poet is a Pregnancy: Pregnant Poets, Body Metaphors, and Cultural Production in Medieval Ireland," The Journal of English and Germanic Philology 108 , no. 4 (2009): 481-505; and Norris Robinson, Satirists and Enchanters in Early Irish Literature (Santa Barbara: American Committee for Irish Studies, 1970).

${ }^{39}$ Ó Cathasaigh, "The Literature of Medieval Ireland,” 20. 
The description of the fili complements the descriptions of the kings. The community chooses the king, and the fili, as part of the community, hold onto institutional memory, reminding the king of his obligations and what those obligations entail. They also help to legitimize or delegitimize the kings in power. The poet, then, can critique both kings and heroes, discussing what leads to sovereignty, what makes a good king and why, and what the community expects from its leaders. The Irish tales portray their kings through a framework in which the relationship of the king and the people has a contractual nature: both parties have rights and responsibilities and are equal partners, and the fili is in charge of both praising and satirizing those in power. Moving our study to the representation of kingship in several tales from the Ulster Cycle reveals anxiety over Irish sovereignty and over the political and legal role of women in bestowing sovereignty.

\section{KIN(G)SHIP AND COMMUNITY IN THE ULSTER TALES}

Similar to the law tracts, medieval Irish literature has an impressive array of materials available for analysis. The Irish materials tends to be divided into four cycles. The Mythological Cycle deals with the primal races of Ireland, who are often held to be pre-Christian Irish deities. The Ulster Cycle consists of tales about the warriors of Ulster. ${ }^{40}$ The Finn Cycle centers on the warriors led by the mythical Finn Mac Cumhaill. The fourth group consists of the king tales, namely tales about the kings of Ireland, historical or mythical. In addition to the four cycles, there are also the immrama, or voyage tales, about pagan or Christian men voyaging on the sea, as well as learned materials, such as genealogies, treatises and, placelore, and a great deal of poetry among others. ${ }^{41}$ This section concentrates on three tales from the Ulster Cycle that show a preoccupation with sovereignty.

Scéla Conchobair maic Nessa ("The Tidings of Conchobar Son of Ness"), Mesca Ulad ("The Intoxication of the Ulstermen"), and Loinges mac nUislenn ("The Exile of the Sons of Uisliu") either question or support Conchobar's legitimacy as the king of Ulster. James Carney and Joanne Findon point out that in texts such as the Táin, Fled Bricrend, and Scéla Muicce Meic Dá Thó, Conchobar's kingship is described in a positive manner. ${ }^{42}$ Nevertheless, Maire Ní Mhaonaigh, in a discussion of the portrayal of women in Irish literature, and Findon, in her essay on Nes, Deirdriu, and Lauine, observe the negative effects of

\footnotetext{
${ }^{40}$ Some of the chief characters of the Ulster Cycle include Conchobar, King of Ulster; Cú Chulainn, the main hero of the Ulster Cycle; Lóeg, charioteer and companion of Cú Chulainn; Fergus, an early King of Ulster who is replaced by Conchobar and later joins the province of Connacht; Conall Cernach, the foster brother of Cú Chulainn; and Sencha, a druid and poet.

${ }^{41}$ Maria Tymoczko, Translation in a Postcolonial Context: Early Irish Literature in English Translation (Manchester, UK: St Jerome, 1999), 12-13.

${ }^{42}$ James Carney, Studies in Early Irish Literature and History (Dublin: Dublin Institute for Advanced Studies, 1955), 234; and Joanne Findon, "Nes, Derdriu, Luaine: Fated Women in Conchobar's Life," in Gablánach in Scélaigecht: Celtic Studies in Honour of Ann Dooley, ed. Sarah Sheehan, Joanne Findon, and Westley Follett (Dublin: Four Courts Press, 2013), 154.
} 
Conchobar's rule. ${ }^{43}$ Findon in particular notes that "Conchobar's kingly career begins brilliantly," but that his "later years seem marked by poor judgment." 44 Although the Ulster tales are not uniform in their representation of Conchobar, an analysis of Conchobar's relationships with the men and women represented in the tales demonstrates some of the ways that the law and the literature relate. Perhaps more important is that the women are the characters that most recall the law within these texts.

The Ulster tales are remarkably consistent with the themes, motifs, and tools that they used to present kingship. Conchobar, for example, maintains friendship with his subjects by giving gifts and granting favors, among other things. The tales also depict Conchobar's mythic and religious relationship with the land that sustains his sovereignty over his people. This is represented by the land producing a bountiful harvest and by describing moments of peace in the territory when Conchobar is presented as the rightful ruler, and the land becoming infertile and by describing conflict in the community when Conchobar's kingship is questioned. The tales discussed function within a system similar to the kingship structure presented in the first section of this article at the same time that they also include women as part of the community that chooses the king. Women have the capacity to place Conchobar in power or to question his rule.

Often in the study of narrative literature there is another aspect of succession and kingship that is used to discuss the role of women in Irish literature, namely the relationship of the king with goddess figures as represented by the female partner of the king. Sacral kingship positions women as the figure of sovereignty in which the female body represents the land, and women play a part in legitimizing the next king. ${ }^{45}$ The discourse of women as figures of sovereignty begins with the supposition that the women in the tales are often reflections of goddesses and exhibit, in one way or another and to various degrees, the different characteristics that mark them as goddesses: they are representations of war, love, land, the happy otherworld, and sovereignty. The goddess of sovereignty represents the land, its soil, substance of territory, and legal and spiritual dominion; she is primarily concerned with the prosperity of the land, its fertility, its animal life, and its security against external forces. Proinsias Mac Cana argues that such women are characterizations of the divine, and it is common for them to play a mythological role rather than a personal one. ${ }^{46}$ Women represent the land and, as representations of the land, also elect the kings. ${ }^{47}$ Some Celtic goddesses are

\footnotetext{
${ }^{43}$ Máire Ní Mhaonaigh, "The Literature of Medieval Ireland, 800-1200: From the Vikings to the Normans," in The Cambridge History of Irish Literature, ed. James Kelleher and Philip O'Leary, vol. I (Cambridge: Cambridge University Press, 2006), 52; and Findon, "Nes, Derdriu, Luaine," 170. Findon concludes that "Conchobar's failure to reach his potential as a ruler likely had much to say to late medieval audiences about kingship and the fraught roles that women can play in public and private life" (170).

${ }^{44}$ Ní Mhaonaigh, "The Literature of Medieval Ireland," 154.

${ }^{45}$ Studies on sovereignty include Tomás Ó Máille, "Medb Chrúachna," Zeitschrift für celtische Philologie 17 (1928): 129-46. R. A. Breatnach, "The Lady and the King: A Theme of Irish Literature," Studies: An Irish Quarterly Review 42, no. 167 (1953): 321-36; Máire Bhreathnach, "The Sovereignty Goddess as Goddess of Death?" Zeitschrift für celtische Philologie 39 (1982): 243-60; and Proinsias Mac Cana, "Aspects of the Theme of King and Goddess in Irish Literature," Études celtiques 7, no. 1-2 (1955-56): 76-114.

${ }^{46}$ Proinsias Mac Cana, Celtic Mythology (Hamlyn: Feltham, 1985), 84.

${ }^{47}$ Proinsias Mac Cana describes the role of women as sovereignty goddesses as follows. "In the
} 
considered divine mothers connected to the land. For example, Anu, an Irish goddess, is associated with two mountains in Kerry named Dá Chich Anann or "the two paps of Anu."

There is a goddess called In Flaithius ("The Sovereignty") who offers the drink of succession, and in many instances is represented by the puella senilis or the hag who becomes a beautiful woman when she unites with the rightful king. ${ }^{49}$ Amy C. Mulligan offers a succinct description of The Sovereignty:

When Ireland suffers famine, war, or lacks an effective leader, then sovereignty is aged, ugly, and infertile. When she encounters the right ruler, someone who will treat Ireland well, perhaps free it from unjust or foreign rule, she regains her idealized feminine form. The many accounts in which Ireland is represented as a woman have been explained by association with female and deities, or tutelary goddesses, in pagan Celtic tradition. ${ }^{50}$

The most famous Irish story of this type is Echtra mac nEchach Muigmedóin, or "The Adventure of the Sons of Eochaid Muigmedón." 51 In this, Niall of the Nine Hostages consummates a union with the hag, who then transforms into a young woman and gives Niall and his descendants the kingdom of Ireland. The story of Niall exhibits several themes associated with sacral kingship, including the giving of a drink. In many occasions giving an eligible candidate a drink signals that the woman chooses him as a partner. ${ }^{52}$ Whether the tales use the motif of the hag turning into a beautiful woman, the woman giving a drink to the man, or sexual intercourse, the woman chooses the rightful king. Nevertheless, the women are not just goddess figures, but more importantly, they are members of a community which chooses the king.

Although goddess figures are important for a critical examination of kingship in medieval Irish literature, scholars have recently begun to question the

traditions of the insular Celtic peoples the feminine embodiment of the realm is of necessity coeval with it; she cannot die except if the realm itself dies, or is destroyed. But she can be, and in the nature of things very often is, bereaved of the human partner who is her elected spouse and the temporal custodian of her domain." "Women in Irish Mythology," The Crane Bag 4, no. 1 (1980): 7.

${ }^{48}$ Mac Cana, "Women in Irish Mythology," 10.

${ }^{49}$ Maria Tymoczko, The Irish Ulysses (Berkley: University of California Press, 1994), 100. This is a motif made infamous by the character of the Wife of Bath in Geoffrey Chaucer's Canterbury Tales (c. 1400). R. A. Breatnach, "The Lady," 335-36.

${ }^{50}$ Mulligan, "Playing for Power," 75.

${ }^{51}$ The tale is found in several manuscripts including the Yellow Book of Lecan, and Leabhar Bhaile an Mhóta or the Book of Ballymote (Dublin, Royal Irish Academy, MS 23 P 12) among others. Both books are dated to the fourteenth or fifteenth centuries. Niall is purported to exist between the fourth and fifth centuries. He and his ancestors are mentioned in early Irish annals, chronicles that cover important people and events in early Irish culture and date to the ninth century. Nevertheless, the tale is written in Middle Irish and dates after the eleventh century. See Whitley Stokes, ed. and trans., "The Death of Crimthann Son of Fidach, and the Adventures of the Sons of Eochaid Muigmedón," Revue Celtique 24 (1903): 172; and Tom Peete Cross and Clark Harris Slover, ed. and trans., "The Adventures of the Sons of Eochaid Mugmedon," in Ancient Irish Tales (1936; repr., New York: Barnes and Noble Books, 1996), 508.

${ }^{52}$ Mac Cana, "Women in Irish Mythology," 8. 
emphasis on the motif in existing scholarship. ${ }^{53}$ Irish literature, in fact, presents an exciting range of roles for women, from warriors to satirizers to sovereignty goddesses; to stereotype them only as sovereignty goddesses limits the analysis of women as literary characters. ${ }^{54}$ Although kingship and its role in the tales is an indicator of the role of women as a vital part of early Irish society, it has also narrowed the scope of analysis. Scéla Conchobair maic Nessa, Mesca Ulad, and Loinges mac nUislenn portray women as important for legitimizing Conchobar by either supporting or challenging his right to kingship, but their actions move beyond the sovereignty motif. They connect Conchobar's rule to kingship as expressed in the law.

In Scéla Conchobair maic Nessa, Ness, daughter of Eochaid Sálbuide and the mother of Conchobar, is a warrior. Her foster parents are killed and she destroys the land and the people of the land while trying to find their killers. Later, Ness meets Cathbad at a spring; she becomes his wife, and Conchobar is born. ${ }^{55}$ Conchobar eventually receives the kingship of Ulster because of his mother. Ness bestows kingship upon her son by marrying Fergus, the king of Ulster prior to Conchobar. Fergus asks her for her hand in marriage, and Ness agrees to marry him with the condition that Conchobar rule for a year in his stead. With the counsel of his men, Fergus obliges. Ness then tells Conchobar how to make the men of Ulster follow him instead of Fergus, which leads to his taking of the kingship. ${ }^{56}$ Ness teaches Conchobar to act as a king by telling him how to gain the goodwill of the men of Ulster, who then proclaim him king.

Ness's marriage to Fergus did not solidify Fergus's position as king. Instead, she stripped his kingship from him by tricking him and gave it to Conchobar. ${ }^{57}$

\footnotetext{
${ }^{53}$ See, for example, Joanne Findon, A Woman's Words: Emer and Female Speech in the Ulster Cycle (Toronto: University of Toronto Press, 1997); Mulligan, "Playing for Power;" and Sarah Sheehan, "Loving Medb," in Gablánach in Scélaigecht: Celtic Studies in Honour of Ann Dooley, ed. Sarah Sheenan, Joanne Findon, and Westley Follett (Dublin: Four Court Press, 2013), 171-86.

${ }^{54}$ Findon, A Woman's Words, 9.

${ }^{55}$ There are several versions of the tale. This essay describes the version in the Book of Leinster. In another version of the tale Cathbad is a druid. For an English translation of this version see Thomas Kinsella, trans., "Before the Táin," in The Táin: Translated from the Irish Epic Táin Bó Cúailnge (1969; Oxford: Oxford University Press, 2002), 3-6. For more information on Ness and her role in the differing versions of the story, see Joanne Findon, "Mother Knows Best: the Role of Ness in Compert Conchobuir," in Ulidia III: Proceedings of the Third International Conference on the Ulster Cycle of Tales, Coleraine, 22-25 June, 2009, ed. Gregory Toner and Séamus Mac Mathúna (Berlin: Curach Bhán, 2013), 25-35.

${ }^{56}$ Sections 7 and 8 read as follows. "Now on that day year the end of that time arrived. Thereupon Fergus, claimed his pledges. 'A colloquy about it!' say the Ulstermen. They took counsel in a single assembly. They deemed it a great dishonor that Fergus had given them (to Ness) as a bride-price. But they were thankful to Conchobar for his goodly gift to them. This then was their suffrage: 'What Fergus sold, let it part from him: what Conchobar bought let it stay with him.' . . So 'tis then that Fergus parted from the kingship of Ulster, and 'tis then that Conchobar was called the overking of a fifth of Ireland" ("Tanic didu cend na ree hísin dia blíadne. Dorimgart i suidiu Fergus a giallu. Immacallaim immi, or Ulaid. Ro imraidsetar i n-oendáil. Ba dímicin mór leo Fergus dia tabairt hi tindscra. Roptar buidig immorro do Chonchobor ar a degthidnacul dóib. Bas sí immorro a n-immacallaim, an ro rir Fergus scarad dó friss: an ro chennaig Conchobar anad aici. ... . Is andsin tra ro scar Fergus fri ríge n-Ulad, ocus iss andsin tra ro congaired ardrige choicid Herenn do Chonchobor mac Cathbad"). Stokes, "Tidings of Conchobar," 25, 24.

${ }^{57}$ Conchobar is associated with his mother instead of his father. The norm was for both men and women to take a patronymic instead of a matronymic, marking Conchobar as distinct and emphasizing the important role of Ness in Conchobar's kingship.
} 
Conchobar does not become high king by the blessing of the goddess; he becomes king because of his mother. Findon remarks that "even in her the deception of Fergus in the Book of Leinster version, she is working with the prophecies about her son's kingly future, helping his destiny to be fulfilled." 58 Ness is not usurping the kingship of Fergus, but cementing Conchobar's success in gaining the kingship. Her role is political and leads to her son becoming king.

Although Conchobar is able to gain the kingship with help from his mother, he also needs the approval of the men of Ulster, which he receives by following his mother's advice. Moreover, his legitimacy becomes apparent because the men honor him, he has sexual intercourse with every woman before she is married, and the land produces bounty:

Ba mór ind airmitiu tra doratsat Ulaid do Chonchobur. Ba si a airmitiu ám leo .i. cech fer di Ultaib doberad ingin macdacht, a feiss la Conchobar in chetaidchi, co mbad hé a cétmunter.

Ni rubai for talmain gein bad gáithiu. Nocho ruc breith ríam uair nocho léichthe do, fobith na rucad gubreith, naptis messaiti a thorthi.

Great, indeed, was the reverence that the Ulstermen gave to Conchobar. This truly was the reverence they had - namely, when any man of the Ulaid married a grown-up girl, she slept with Conchobar on the first night, so that he became her first husband.

On earth has been no wiser being. He never delivered a judgment at a time when it was not permitted him, in order that he might not deliver a false judgment, so that his crops might not be the worse thereof. ${ }^{59}$

Conchobar demonstrates his fir flathemon and the Ulstermen gain a new king. Conchobar receives the kingship of Ulster through his mother, the daughter of a king, and the men of the community, and he is able to maintain kingship because the land is prolific and he is wise. Ness is crucial to Conchobar's rise to kingship; she belongs to the community that places him in power and she understands the laws that can secure him the kingship. Similarly, Emer, the wife of Cú Chulainn, voices that Conchobar is king in Mesca Ulad.

At the beginning of Mesca Ulad, Conchobar's sovereignty is validated by the community and by his fir flathemon. The kingdom of Ulster is divided among Conchobar, Cú Chulainn mac Sualtain, and Fintan mac Néill Níamglonnaig. Sencha mac Ailill and Cathbad convince Cú Chulainn and Fintan respectively to let Conchobar rule the province for a year, and, if Conchobar is the rightful king, to let him keep the kingship of Ulster. ${ }^{60}$ The first to advocate for Conchobar are

\footnotetext{
${ }^{58}$ Findon, "Nes, Derdriu, Luaine," 161.

${ }^{59}$ Stokes, "Tidings of Conchobar," 24, 25.

${ }^{60}$ The Irish text states that "[Conchobar] is the spring of rightful proprietorship no one can claim against or challenge, descendant of the kings of Ireland and Britain." John T. Koch and John Carey, ed., "Mesca Ulad The Intoxication of the Ulstermen," in The Celtic Heroic Age: Literary Sources for Ancient Celtic Europe \& Early Ireland \& Wales, $4^{\text {th }}$ ed. (Aberystwyth: Celtic Studies Publications, 2003), 107. "Is é in tipra 'na telluch thechtaide é na fétaither d'athgúd ná d'éligud, úa ríg Hérenn is Alban." Watson, Mesca Ulad, 4.
} 
the learned men of the community. Conchobar proves his right to kingship and becomes sole ruler of the province of Ulster:

9 12. In tí thánic i cind blíadna, ro boí in cóiced ina thopor thuli 7 téchta ac Conchobar, cona rabi aithles fás falam ótá Rind Semni 7 Latharnai co Cnocc Úachtair Fhorcha 7 co Duib 7 co Drobaís cen mac i n-inad a athar 7 a shenathar ic tairgnam da thigernu dúthaig.

913. Is and so do-rala caínchomrád etir Coin Culainn 7 Emir. / 'Atar lim,' ar Emer, 'is ardri Ulad ifechtsa Conchobar.' / 'Ní líach cíambad ed,' ar Cú Chulainn. / 'Is mithig a choibled rígi do dénam dó badechtsa,' ar Emer, 'ar is rí co suthain é.' / 'Déntar didiu,' bar Cú Chulainn.’'61

9 12. [For] anyone who came at the end of a year, the province was as a gushing spring and [there was] rightfulness with Conchobar, so that from the Peak of Semne and Lathairne to the Hill of the Summit of Forcha and to Dub and to Drobais there was not an abandoned ring-fort, not one without the son in the place of his father and grandfather serving his legitimate lord.

9 13. It was then that a fine conversation between Cú Chulainn and Emer took place. 'It seems to me,' Emer said, 'that Conchobar is now high-king of Ulster.' 'If so, there is nothing wrong with that,' Cú Chulain said. 'It is now time to make his feast of kingship for him,' Emer said, 'for he is king forever.' 'It shall be made then,' Cú Chulainn said. ${ }^{62}$

The scene demonstrates Conchobar's worthiness to hold sovereignty over Ulster because the men of Ulster ask for Conchobar to rule, the community follows the right protocols, the land becomes fertile, and there is peace under his kingship. Furthermore, the scene depicts Emer, the wife of Cú Chulainn, declaring Conchobar king twice. She states that he is ardri (high king), and that he is $r i$ (king) always. Cú Chulainn acknowledges her statement - that the land is better for Conchobar being king. The conversation between Emer and Cú Chulainn, who had access to kingship, highlights that Conchobar is the rightful ruler. Emer uses the kingly terminology and tells Cú Chulainn how to react. The tale allows Emer to participate in acknowledging Conchobar's kingship.

Although the rest of the tale raises questions about Ulster heroism, pointing to the possible destruction that heroes can bring to the community ${ }^{63}$ the beginning

\footnotetext{
${ }^{61}$ Watson, Mesca Ulad, 6-7 (emphasis added).

${ }^{62}$ Koch and Carey, "Mesca Ulad," 108-09 (emphasis added).

${ }^{63}$ Ní Mhaonaigh, "Literature of Medieval Ireland,” 51. Ní Mhaonaigh describes several tales that question the heroic exploits of the Ulstermen. She writes that "in [Mesca Ulad], the would-be warriors are comically presented as engaging in a drunken night-march which brings them not to Cú Chulainn's citadel, their intended destination, but to far-away Temair Lúachra in the south-west, where many of them are burned to death in an iron house" (52).
} 
of the tale leaves no doubt about Conchobar's legitimacy as king of Ulster. Peace, acceptance by his retinue (including women of standing), and the prosperity of the land are all important qualities for Conchobar to be king. Both Scéla Conchobair maic Nessa and Mesca Ulad position women as part of the community that chooses Conchobar as king. Ness becomes an active political agent that is crucial in Conchobar's gaining of the kingship, and Emer's position as the wife of Cú Chulainn, a man who has access to kingship and who was acting as king at the beginning of the tale, allows her to have a wider view of the situation and to speak with truth. Emer becomes the voice that acknowledges that he is the rightful king. Although neither of these characters are functioning as sovereignty goddesses, they are critical in solidifying the position of Conchobar as king, and they both seem to understand the legal aspects of kingship.

In Loinges mac nUislenn ("Exile of the Sons of Uisliu"), however, Conchobar's sovereignty is questioned by using the same literary motifs described above to hint that the kingdom should now belong to a different man. The tale begins at a gathering in which Deirdre, a character who later has aspects of a sovereignty goddess, ${ }^{64}$ screams from inside her mother's womb. Cathbad prophesizes that Deirdre would be beautiful and would bring destruction to the Ulstermen. The Ulstermen want to kill the unborn baby, but Conchobar does not follow the advice of his men and decides to have her grow in seclusion until she becomes his wife.

Once Deirdre reaches womanhood, however, she rejects Conchobar for Noísiu, a much younger man who is able to make a claim for the kingship of Ulster:

Fecht n-and didiu baī-seom int-í Noísi a óenur for dóe inna rrátha .i. ina Emna, oc andord. Ba bind immurgu a n-andord mac n-Usnig. Cech bó ocus cech míl ro·chluined, no·mbligtis dā trian blechta d'immarcraid ūadib. Cech duine rod·chluined, ba lór síthchaire ocus airfitiud dóib. Ba maith a ngaisced dano. Cīa no beth cōiced Ulad i nōen-baili impu, acht corro chuired cách díb a triur a druim fri araile, ni·bertais búaid diib ar febas na ursclaige ocus na imdíten. Bat comlūatha dano fri conaib oc tafonn. No marbdais na fiada ar lúas. ${ }^{65}$

This man Noisiu was chanting by himself one time near Emain, on the rampart of the stronghold. The chanting of the sons of Uisliu was very sweet. Every cow or beast that heard it gave two thirds more milk. Any person hearing it was filled with peace and music. Their deeds in war were great also: if the whole province of Ulster came at them at once, they could put their three backs together and not be beaten, their parrying and defense were so fine. Beside this they were swift as hounds in the chase, killing the wild beasts in flight. ${ }^{66}$

The sons of Uisliu have the qualities needed to be king. They can make the land

${ }^{64}$ Maria Tymoczko, “Animal Imagery in Loinges mac nUislenn,” Studia Celtica 20-21 (198586): 155 .

${ }^{65}$ Hull, Loinges, 45.

${ }^{66}$ Kinsella, "Before the Táin,” 12. 
produce, they bring peace to their people, and they can protect the territory ${ }^{67}$ Directly following the moment described above, Deirdre goes to Noísiu and forces him to accept her as his partner, despite the fact that she is intended for Conchobar. In foregrounding her choice of Noísiu, the tale questions Conchobar's right to sovereignty because she is not accepting his rule over her body.

As the tale continues, Deirdre and the sons of Uisliu are exiled for a period of time. The men of Ulster ask for their return, and Conchobar sends the sons of Uisliu word that they can come back. They are, however, betrayed by Conchobar, which leads to the destruction of Ulster. Fergus, Dubthach, and Cormac had promised that no harm would come to the sons of Uisliu if they returned. In addition, Fergus's son, who was with the sons of Uisliu to make sure they would be received safely, is killed. Conchobar not only betrays the brothers, he also kills Fergus's son, and in the process forces Fergus, Dubthach, and Cormac to avenge the deaths of the sons of Uisliu or lose their honor:

Ro·marbtha iar suidiu sethnón na faithche conna térna ass acht a ndechtaid do rind gaī ocus di giun chlaidib; ocus rucad-si in-nunn co Conchobor co·mbaí fora láim ocus ro·cumrigthe a lláma íarna cúl.

At $\cdot$ chūas do Fergus iarum an-í-sin ocus do Dubthach ocus do Chormac. Tāncatar side co ndernsat gníma móra fo chēt-óir .i. Dubthach do marbad Mane maic Conchobuir ocus Fiachna mac Feidilme ingine Conchobuir do guin dond ōen-fogab ocus Fergus do marbad Thraigthrēoin maic Traiglethain ocus a brāthar ocus sārugud Conchobuir impu ocus cath do thabairt eturru iar sin isind ōen-lōu co torchratar tri chét de Ultaib eturru ocus in-genrad Ulad do marbad do Dubthach rīa matain ocus Emain do loscud do Fergus. ${ }^{68}$

Then the slaughter broke out all over the green. No one left except by spike of spear or slash of sword. Deirdre was brought over to Conchobor and stood beside him with her hands bound at her back.

Fergus was told of this, and Dubthach and Cormac. They came at once and did mighty deeds. Dubthach killed Maine, Conchobor's son. Fiachna, son of Conchobor's daughter Fedelm, was killed with a single thrust. Fergus killed Traigthrén, Traiglethan's son, and his brother. Conchobor was outraged, and on a day soon afterward battle was joined between them, and three hundred among the men of Ulster fell. Before morning Dubthach had massacred the girls of Ulster and Fergus had burned Emain. ${ }^{69}$

The men and women of Ulster are killed, and Fergus, Dubthach, Cormac, and their followers leave Ulster. Conchobar's actions and his choice to break his promise to the sons of Uisliu signal the beginning of the decline of the

\footnotetext{
${ }^{67}$ Tymoczko, “Animal Imagery,” 156.

${ }^{68}$ Hull, Loinges, 47-48.

${ }^{69}$ Kinsella, "Before the Táin,” 15.
} 
Ulstermen. ${ }^{70}$ Emain Macha, the capital of the Ulstermen, is burnt down, and the heroes and the young women of Ulster are exiled or killed. The tale demonstrates the opposite of fir flathemon.

The death of the sons of Uisliu brings about a transformation in Deirdre. She stops smiling, combing her hair, and eating. The motif of the puella senilis or the hag that transforms into a beautiful woman is reversed when Deirdre's beauty is diminished by her grief. A different transformation occurs through Deirdre's speech, however: she begins the tale making noises associated with cattle and animals when she is still in her mother's womb and ends reciting poetry, ${ }^{71}$ in part, to lament the loss of Uisliu. One of the poems ends:

"Fáilte, in-diu ni-dam úain

I ndáil Emna - ercdair saír -

Na síd na suba na sám

Na tech már na cumtach caín. ${ }^{72}$

What use for welcome have I now

with all these nobles crowding Emain?

Comfortless, no peace (sid) nor joy,

nor mansion nor pleasant ornament. ${ }^{73}$

The primary definition of the word sid in DIL is "a fairy hill or mound . . . Later in a more general sense, wondrous, enchanting, charming, delightful."74 Yet there is also a second entry for sid in the dictionary that connects the word to a state of peace:

2 sid, sith . . . (a) peace, goodwill, peaceableness; a state of peace; a period of peace, a truce; terms of peace; peacemaking, pacification, conciliation . . . (b) a peace-offering, compensation, atonement, indemnity; compact of peace; in pl. peace-conditions . . . (c) pardon, forgiveness ... (d) of natural phenomena, peace, quietness, stillness. ${ }^{75}$

In the poem, sid has the connotation of peace; more specifically, Deirdre is lamenting that she does not have this state of peace. Moreover, she connects the lack of peace with the "nobles crowding Emain." The poem is recited after Conchobar has killed the sons of Uisliu, Emain has burned down, and men of standing - heroes such as Fergus and Cormac — are exiled. The men surrounding Emain at this time are the ones who survived the destructive skirmish. Her lament on lack of peace reflects the fact that the men left in Emain brought the opposite of peace to the people of Ulster.

\footnotetext{
${ }^{70}$ Tymoczko, “Animal Imagery,” 158.

${ }^{71}$ Ann Dooley, "The Heroic World: The Reading of Early Irish Sagas," in The Celtic Consciousness, ed Robert O’Driscoll (New York: George Braziller, 1982), 156-57; Tymoczko, "Animal Imagery," 154.

${ }^{72}$ Hull, Loinges, 50 (emphasis added).

73 "Kinsella, Before the Táin," 18 (emphasis added).

${ }^{74}$ Dictionary of the Irish Language, 541.

${ }^{75}$ Dictionary of the Irish Language, 541.
} 
As a result of her poetry, Deirdre becomes a poetic figure whose death signals the death of Emain. Her recitations demonstrate an understanding of the law and of fir flathemon. She laments that Conchobar did not act accordingly and brought the opposite of peace. The decline is made more apparent when Deirdre kills herself so that she does not have to be with both Conchobar and Éogan, Noísiu's killer. ${ }^{76}$ By the end of the story, Conchobar has broken his word, brought death and strife to his people, and caused the burning of his homeland. His actions produce the opposite effects of those associated with legitimate sovereignty.

The women presented in these texts-Ness, Emer, and Deirdre - have a political and legal role that gives Conchobar legitimacy or takes his legitimacy away. Ness and Emer participate in choosing Conchobar as king, and Deirdre, who is the character most resembling a sovereignty goddess, does not. Moreover, Deirdre, unlike Ness and Emer, is raised away from her society, in seclusion from the community, and unable to make decisions beyond the walls of her confinement. Once Deirdre becomes part of the community, she continues to voice her displeasure of Conchobar and demonstrate Conchobar's failings as king by becoming a poet who "refuses to be party to the human and societal destruction that could ensue from her dehumanization." 77 She continues to question Conchobar's legitimacy without being subsumed into the role of sovereignty goddess. The tales tend to reinforce the ideals of kingship through women who operate with an understanding of the law. These three tales taken together demonstrate the dangers of excluding women from the community that legally chooses the king.

Ness, Emer, and even Deirdre are active in their community, as they voice their choice to kingship. Ann Dooley commenting on the Lebor na hUidre's version of the Táin and Joanne Findon on both extant versions of Tochmarc Becfhola agree that the tales may have an active female audience. ${ }^{78}$ Findon observes that

In a context of such political and cultural confidence, the stories of King Conchobar's dealings with women, and their negative effects on his relationship with his warriors, might have been read as a warning to those in authority of how the abuse of power can jeopardize political gains. Competition between men for younger women, the various types of violence perpetrated against these women, and the resulting instability of the community, all suggest a critique of the society within

\footnotetext{
${ }^{76}$ Conchobar decides to share Derdrie with Éogan and she kills herself: "They set out the next day for the fair of Macha. She was behind Eogan in the chariot. She had sworn that two men alive in the world together would never have her. / 'This is good, Derdriu,' Conchobor said. 'Between me and Eogan you are a sheep eyeing two rams.' / A big block of stone was in front of her. She let her head be driven against the stone, and made a mass of fragments of it, and she was dead" ("Lotar īarna bárach do ōenuch Macha. Buí-si īar cúl Eogain i carput. Do rarngert-si na·haicc-fiuth a dā cēile for talmain i n-ōen-fecht. / 'Maith, a Derdriu,' ol Conchobor, 'súil chǣrach eter dā rethe gnīi-siu etrum-sa ocus Eogan.' / Ro'baí ail chloiche mór ara cinn. Do·llēici a cenn immon cloich co·nderna brúrig dia cinn co-mbo marb." Hull, Loinges, 51). Kinsella, "Before the Táin,” 19-20.

${ }^{77}$ Tymoczko, “Animal Imagery,” 153.

${ }^{78}$ Ann Dooley, Playing the Hero: Reading the Irish Saga Táin Bó Cúailnge (Toronto: University of Toronto Press, 2006), 77; Joanne Findon, "Looking for 'Mr. Right' in Tochmarc Becfhola," in Constructing Gender in Medieval Ireland, ed. Ann Dooley and Sarah Sheehan (New York: Palgrave Macmillan, 2013), 70, Kindle edition.
} 
these texts. $^{79}$

Indeed, competition between men for women and violence against women could also imply a preoccupation with kingship from a broader pan-European political perspective in which the female body is used to legitimize conquest. Sharon Kinoshita effectively argues that in La Prise d'Orange (end of the twelfth century), the female body becomes the vehicle and the motivation for conquest, vindicating French feudal aggression against Saracens. ${ }^{80}$ She notes that "by gendering its politics of conquest, La Prise d'Orange anticipates the strategy of later colonial administrations that sought to collaborate with the women under the pretext of liberating them from oppression by their own men." 81 The use of the female voice to accept kingship or to criticize the abuse of power and the distancing of the sovereignty motif implies a preoccupation with the use of the female body to transgress against Irish sovereignty. The inclusion of women in the texts and the possibility of women controlling "meaningful conduct" 82 as well as controlling lawful conduct works against the discourse of feudal transgression, a discourse used by the Anglo-Normans as early as the eleventh century in the First Crusade. ${ }^{83}$

\section{KIN(G)SHIP, POWER, AND THE FILI}

The Ulster tales discussed above indicate that Conchobar's choices affect those around him. The texts repeatedly deal with the right of the king to power and the notion that his actions directly affect the people and the land. Because the tales deal with the aristocratic community, and because they introduce said community as the whole culture, the texts imply that the whole community-including the heroes, the poets, the women, and even the land-has a voice. The kings are not beyond reproach, and the nature of their relationship to their kingdoms and retinues is such that the community can question them. The Irish tales present a delicate balance between praising the kings for their amazing deeds and chastising them for ultimately leading to the downfall of their people and the lands they

\footnotetext{
${ }^{79}$ Findon, “Nes, Deirdriu, Luaine," 170.

${ }^{80}$ Kinoshita, Medieval Boundaries: Rethinking Difference in Old French Literature (Philadelphia: University of Pennsylvania Press, 2006), 72-73.

${ }^{81}$ Kinoshita, Medieval Boundaries, 72. Other French texts that have similar themes to La Prise d'Orange include Floire et Blanchefleur, Cligès, and the Conquête de Constantinople. Two late medieval Catalan texts that use similar themes are Curial et Guelfa and Tirant lo Blanc.

${ }^{82}$ Dooley, Playing the Hero, 163.

${ }^{83}$ Geraldine Heng demonstrates that one of the themes of the Historia Regum Brittaniae which becomes paramount in Romance is "the rescuing of aristocratic maidens." "Cannibalism, the First Crusade, and the Genesis of Medieval Romance," Differences: A Journal of Feminist Cultural Studies 10, no. 1 (1998): 125. Heng discusses the use of the motif to explain male aggression against the Other in an Anglo-Norman context. The Anglo-Normans used the female body as part of feudal transgression against Wales as well. See, for example, Katherine Millersdaughter, "The Geopolitics of Incest: Sex, Gender and Violence in the Fourth Branch of the Mabinogi," Exemplaria 14, no. 2 (2002): 271-316.
} 
should have protected. After all, this is the role of the fili in Irish society, and the role that Deirdre fulfills at the end of her tale.

Ultimately, the fili, clerics, and lay men of Ireland conserved these stories and in many occasions embellished them. The ideology that those in power should have a legitimate assembly with the community and the land would have resonated with those that copied and rewrote the tales. The stories point out that those with a right to sovereignty must be connected to the community, a prerequisite that the recently arrived Anglo-Normans in Ireland did not possess in the twelfth century but that their descendants could certainly have claimed and possibly did by the fifteenth.

University of New Mexico 
Bibliography

Archan, Christophe. "Ordeal by Fire in Medieval Ireland." Peritia 24-25 (201314): 197-212. https://doi.org/10.1484/J.PERIT.5.102747

Bhreathnach, Máire. "The Sovereignty Goddess as Goddess of Death?" Zeitschrift für celtische Philologie 39 (1982): 243-60. https://doi.org/10.1515/zcph.1982.39.1.243

Binchy, Daniel A. Celtic and Anglo-Saxon Kingship. Oxford: Oxford Clarendon Press, 1970.

—. "The Date and Provenance of Uraicect Becc." Ériu: The Journal of the School of Irish Learning 18 (1958): 44-54.

— ed. Crith Gablach. Dublin: Dublin Institute for Advanced Studies, 1941.

Breatnach, Liam, ed. and trans. "The First Third of Bretha Nemed Tóisech." Ériu: The Journal of the School of Irish Learning 40 (1989): 1-40.

- ed. and trans. Uraicecht na Riar: The Poetic Grades in Early Irish Law. Dublin: Dublin Institute for Advance Studies, 1987.

— . "Canon Law and Secular Law in Early Ireland: The Significance of Bretha Nemed." Peritia 3 (1984): 439-59. https://doi.org/10.1484/J.Peri.3.78

Breatnach, Pádraig A. "The Chief's Poet." Proceedings of the Royal Irish Academy 83, C (1983): 37-79.

Breatnach, R. A. "The Lady and the King: A Theme of Irish Literature." Studies: An Irish Quarterly Review 42, no. 167 (1953): 321-36.

Byrne, Francis Jones. Irish Kings and High-Kings. Dublin: Four Courts Press, 2001.

Carney, James. Studies in Early Irish Literature and History. Dublin: Dublin Institute for Advanced Studies, 1955.

Charles-Edwards, Thomas. M. "A Contract between King and People in Early Medieval Ireland? Crith Gablach on Kingship." Peritia 8 (1994): 107-19. https://doi.org/10.1484/J.Peri.3.207

—. Early Irish and Welsh Kinship. Oxford: Oxford University Press, 1993. https://doi.org/10.1093/acprof:oso/9780198201038.001.0001

Cross, Tom Peete, and Clark Harris Slover, ed. and trans. "The Adventures of the Sons of Eochaid Mugmedon." In Ancient Irish Tales, 508-13. 1936. Reprint, New York: Barnes and Noble Books, 1996.

Dictionary of the Irish Language: Based Mainly on Old and Middle Irish Materials, Compact Edition. 1983. Reprint, Dublin: Royal Irish Academy, 2007.

Dillon, Myles and Nora K. Chadwick. The Celtic Realms. London: Weidenfeld and Nicolson, 1967.

Dooley, Ann. Playing the Hero: Reading the Irish Saga Táin Bó Cúailnge. Toronto: University of Toronto Press, 2006. https://doi.org/10.3138/9781442678538 
—. "The Heroic World: The Reading of Early Irish Sagas." In The Celtic Consciousness, edited by Robert O'Driscoll, 155-59. New York: George Braziller, 1982.

Findon, Joanne. "Looking for 'Mr. Right' in Tochmarc Becfhola." In Constructing Gender in Medieval Ireland, edited by Ann Dooley and Sarah Sheehan, chapter 3. New York: Palgrave Macmillan, 2013. Kindle edition. https://doi.org/10.1057/9781137076380_4

_. "Mother Knows Best: the Role of Nes in Compert Conchobuir." In Ulidia III: Proceedings of the Third International Conference on the Ulster Cycle of Tales, Coleraine, 22-25 June, 2009, edited by Gregory Toner and Séamus Mac Mathúna, 25-35. Berlin: Curach Bhán, 2013.

—. "Nes, Derdriu, Luaine: Fated Women in Conchobar's Life." In Gablánach in Scélaigecht: Celtic Studies in Honour of Ann Dooley, edited by Sarah Sheehan, Joanne Findon, and Westley Follett, 154-170. Dublin: Four Courts Press, 2013.

—. A Woman's Words: Emer and Female Speech in the Ulster Cycle. Toronto: University of Toronto Press, 1997. https://doi.org/10.3138/9781442670549

Gibson, D. Blair. From Chiefdom to State in Early Ireland. Cambridge: Cambridge University Press 2012. Kindle edition. https://doi.org/10.1017/CBO9781139059022

Heng, Geraldine. "Cannibalism, the First Crusade, and the Genesis of Medieval Romance." Differences: A Journal of Feminist Cultural Studies 10, no. 1 (1998): 98-174.

Hull, Vernan, ed. Loinges mac nUislenn, The Exile of the Sons of Uisliu. New York: Modern Language Association, 1949.

Jaski, Bart. Early Irish Kingship and Succession. Dublin: Four Courts Press, 2000.

Kelly, Fergus. A Guide to Early Irish Law. 1988. Reprint, Dublin: Dublin Institute for Advance Studies, 2015.

— ed. and trans. Audacht Morainn. Dublin: Dublin Institute for Advanced Studies, 1976.

Kinoshita, Sharon. Medieval Boundaries: Rethinking Difference in Old French Literature. Philadelphia: University of Pennsylvania Press, 2006. https://doi.org/10.9783/9780812202489

Kinsella Thomas, trans. "Before the Táin.” In The Táin: Translated from the Irish Epic Táin Bó Cúailnge, 1-50. 1969. Reprint, Oxford: Oxford University Press, 2002.

Koch, John T., and John Carey, eds. "Mesca Ulad The Intoxication of the Ulstermen." In The Celtic Heroic Age: Literary Sources for Ancient Celtic Europe \& Early Ireland \& Wales, 106-127. $4^{\text {th }}$ ed. Aberystwyth: Celtic Studies Publications, 2003.

Latvio, Riitta. "Status and Exchange in Early Irish Laws." Studia Celtica Fennica 2 (2005): 67-96.

Mac Cana, Proinsias. Celtic Mythology. Hamlyn: Feltham, 1985. 
—. "Women in Irish Mythology." The Crane Bag 4, no. 1 (1980): 7-11.

_. "Aspects of the Theme of King and Goddess in Irish Literature." Études celtiques 7, no. 1-2 (1955-56): 76-114.

MacNeill, Eóin. "Ancient Irish Law. The Law of Status or Franchise." Proceedings of the Royal Irish Academy 36 (1923): 265-316.

—. Celtic Ireland. 1921. Reprint, Dublin: The Academic Press, 1988.

McCone, Kim. "'King' and 'Queen' in Celtic and Indo-European." Ériu: The Journal of the School of Irish Learning 49 (1998): 1-12.

Millersdaughter, Katherine. "The Geopolitics of Incest: Sex, Gender and Violence in the Fourth Branch of the Mabinogi." Exemplaria 14, no. 2 (2002): 271316. https://doi.org/10.1179/exm.2002.14.2.003

Mulligan, Amy C. "Playing for Power: Macha Mongrúad's Sovereign Performance." In Constructing Gender in Medieval Ireland, edited by Sarah Sheehan and Ann Dooley, chapter 4. New York: Palgrave Macmillan, 2013. Kindle edition. https://doi.org/10.1057/9781137076380_5

—. "The Satire of the Poet is a Pregnancy: Pregnant Poets, Body Metaphors, and Cultural Production in Medieval Ireland." The Journal of English and Germanic Philology 108, no. 4 (2009): 481-505. https://doi.org/10.1353/egp.0.0073

Ní Mhaonaigh, Máire. "The Literature of Medieval Ireland, 800-1200: From the Vikings to the Normans." In The Cambridge History of Irish Literature. Vol. 1, edited by James Kelleher and Philip O'Leary, 32-73. Cambridge: Cambridge University Press, 2006. https://doi.org/10.1017/CHOL9780521822220.004

Ó Cathasaigh, Tomás. "The Literature of Medieval Ireland to c. 800: St Patrick to the Vikings." In The Cambridge History of Irish Literature. Vol. 1, edited by Margaret Kelleher and Philip O'Leary, 9-31. Cambridge: Cambridge University Press, 2008. https://doi.org/10.1017/CHOL9780521822220.003

Ó Cróinín, Dáibhí. Early Medieval Ireland: 400-1200. London: Longman, 1995.

Ó Máille, Tomás. "Medb Chrúachna." Zeitschrift für celtische Philologie 17 (1928): 129-46. https://doi.org/10.1515/zcph.1928.17.1.129

Robinson, Norris. Satirists and Enchanters in Early Irish Literature. Santa Barbara: American Committee for Irish Studies, 1970.

Sheehan, Sarah. "Loving Medb." In Gablánach in Scélaigecht: Celtic Studies in Honour of Ann Dooley, edited by Sarah Sheenan, Joanne Findon, and Westley Follett, 171-86. Dublin: Four Court Press, 2013.

Simms, Katharine. "The Poet as Chieftain's Widow: Bardic Elegies." In Sages, Saints, and Storytellers: Celtic Studies in Honor of Professor James Carney, edited by Donnchadh Ó Corráin, Liam Breatnach and Kim McCone, 400-11. Maynooth: An Sagart, 1989.

Stacey, Robin Chapman. Dark Speech: The Performance of Law in Early Ireland. Philadelphia: University of Pennsylvania Press, 2007. https://doi.org/10.9783/9780812294040

Stokes, Whitley, ed. and trans., "Tidings of Conchobar Mac Nessa." Ériu: The Journal of the School of Irish Learning 4 (1910): 18-38. 
, ed. and trans. "The Death of Crimthann Son of Fidach, and the Adventures of the Sons of Eochaid Muigmedón." Revue Celtique 24 (1903): 172-207.

Thurneysen, Rudolf, Nancy Power, Myles Dillon, Kathleen Mulchrone, Daniel A. Binchy, August Knoch, and John Sprott Ryan. Studies in Early Irish Law. Dublin: Hodges, Figgis \& Co., 1936.

_. "Morands Fürstenspiegel." Zeitschrift für Celtische Philologie 11 (1917): 56-106. https://doi.org/10.1515/zcph.1917.11.1.56

Tymoczko, Maria. “A Poetry of Masks: The Poet's Persona in Early Celtic Poetry." In A Celtic Florilegium: Studies in Memory of Brendan O. Hehir, edited by Kathryn A. Klar, Eve E. Sweetser, and Claire Thomas, 187-209. Massachusetts: Celtic Studies Publications, 1996.

. "Animal Imagery in Loinges mac nUislenn." Studia Celtica 20-21 (198586): 145-66.

—. The Irish Ulysses. Berkley: University of California Press, 1994.

—. Translation in a Postcolonial Context: Early Irish Literature in English Translation. Manchester: St. Jerome, 1999.

Warntjes, Immo. "Regnal Succession in Early Medieval Ireland." Journal of Medieval History 30 (2004): 377-410.

https://doi.org/10.1016/j.jmedhist.2004.08.004

Watson, J. Carmichael, ed. Mesca Ulad. 1941. Reprint, Dublin: Dublin Institute for Advance Studies, 1983.

Zumbuhl, Mark Joseph. "The Practice of Irish Kingship in the Central Middle Ages." PhD diss., University of Glasgow, 2005. 